\title{
A Study on the Countermeasure of Cruise Home Port Upgrading to Cruise Ship Tourism Destinations in Tianjin
}

\author{
Xiaonan $\mathrm{Li}^{1, \mathrm{a}^{*}}$ \\ ${ }^{1}$ Tianjin Maritime College, No.8, Yashen Raod, Jinnan District, Tianjin City, China \\ aily2019151412@163.com
}

Keywords: Counermeasure; Cruise Home Port; Cruise Ship Tourism Destination; Tianjin

\begin{abstract}
The development of China's cruise tourism market is growing rather rapidly, and it will maintain a high growth in the next few years. But the rapid growth is mainly concentrated in the cruise outbound tourism, which is only the initial stage of cruise tourism. The development prospects should be cruise inbound tourism. This paper focuses on how to upgrade the cruise home port to cruise ship tourism destination, attract international tourists. This paper will start from the development of Tianjin cruise home port, discuss the feasibility of upgrading Tianjin cruise home port to cruise ship tourism destination, and put forward counter measures.
\end{abstract}

\section{Introduction}

In recent years, China's cruise tourism market showed a sustainable growth. According to statistics, in 2015, the top ten ports in China-- Shanghai, Tianjin, Dalian, Yantai, Qingdao, Zhoushan, Xiamen, Guangzhou, Haikou and Sanya received a total number of 629 cruise ships, an increase of 35\% compared to 2014; the total number of entry-exit cruise tourists were more than 2,480,000 people, an increase of $44 \%$ compared to 2014 , becoming the world's fourth largest cruise tourism country. In 2016, the top ten ports in China received a total number of 996 cruise ships, an increase of 58\% compared to 2015, included 913 homeport berthing cruise ships, an increase of $69 \%$ compared to 2015; the total number of entry-exit cruise tourists were more than 4,500,000 people, an increase of $82 \%$ compared to 2015 . With the gradual formation of the cruise brand image and the continuous recognition of cruise tourism, China is expected to become the most important cruise market all over the world with great potential for development. According to estimates, in 2020, China's cruise tourists will reach 5 million passengers.

\section{Cruise Home Port and Cruise Tourism Ship Destinations}

Cruise Home Port and Cruise Ship Tourism Destinations. Cruise port is divided into three categories-Home port, port of call, and Jelly. Cruise home port is provided with facilities and qualification that the large cruises can berth and turnover. Also, it offers comprehensive services and assorts. Home port is the base of the cruises, the cruises are recharged, do waste disposal, maintained and repaired here, the cruise companies locate in the port to set up headquarters.

When the cruise berths at the extension point of the port network, it will berth a long time which is around 4-8 hours. Not only for the sightseeing of tourists, but also the supplements, treatments and wasting disposal; ports of call only provide tourists sightseeing for a short stop. In this type of ports, the berthing time is usually less than 4 hours, without increasing the supply.

In 1988, American scholar Gunn proposed for the first time the concept of destination zone, and the tourism destination is defined as: the tourism resources in a certain geographical space with special tourism facilities, tourism infrastructure and other conditions related to the organic combination for active and stay. That is, tourism destinations. Tourist destinations are sometimes called tourist destinations or tourist attractions under different circumstances. The so-called "cruise destination" refers to the attraction of cruise tourists to stay briefly.

The Differences of Home Port and Cruise Ship Tourism Destinations. A cruise home port needs to have two conditions, one is a good harbor conditions, the other one is the broad tourist market. To become the cruise ship tourism destination needs to attract tourists with cruise ship 
tourism resources; most cruise home ports also have tourist attractions, which mean that the cruise homeport can receive cruise tourists as well as output at the same time. But because of the lack of tourism attraction, it is hard that the homeports become famous tourist destinations in the cities. Civitavecchia-the cruise homeport is called a outer port of Rome which is a famouse cruise ship tourism destination.

\section{Operation Analysis of Tianjin Home Port}

Introduction. Tianjin cruise home port is located in the southern tip of Tianjin Dongjiang port, put into use in 2010. It is the largest cruise home port in the Asian region. Its construction area occupied 1.6 million square meters while the coastline extended 2000 meters long with 6 berths. A development area of 700 thousand square meters was built in the first phase, with 2 large international cruise berths and an assorted passenger station which can accommodate the world's largest cruise ship. The designed passenger capacity is 500 thousand passengers annually. The Second phase of the construction was completed by the end of 2013, connected with the first phase construction and a cruise terminal was established and the total length of coastline is 1067 meters which can accommodate three cruise berths, greatly improving the reception capacity of cruise home port.

The Development of Tianjin Home Port. Tianjin port began to receive international luxury cruises from 2004, received a total of 10 cruise ships, 4840 tourists; In 2005, receiving a total of 8 cruise ships, 7500 tourists; In 2006, a total of 16 cruise ships was received with 32,296 tourists. In 2007, receiving a total of 19 cruise ships and over 40,535 visitors. In August 2007, The Italian Costa cruises "Allegra" utilized the Tianjin port as their home port, expanded Japanese and South Korean itineraries, then Costa Cruise kept Japanese and South Korean itineraries in Tianjin for 3 consecutive years.

After the establishment of Tianjin home port, it received the Costa Cruises, Royal Caribbean Cruise, Azamara Club Cruises, Princess Cruises, Celebrity Cruise, MSC, P\&O Cruises, Compagnie du Ponant, Oceania Cruises, Hapag-Lloyd Cruises, Cunard Cruise, Regent Seven Seas Cruise and Silversea Cruise constantly.

Operation Analysis of Tianjin Home Port. Since the port opened, the reception number of Tianjin home port showed a significant upward trend (Table 1). In recent years, the Tianjin international home port actively adapted to the market demand, and plan to open up new itineraries jointly with the worldwide famous cruise companies(Table 2). "Chinese Cruise Market Research Report online 2016" shows that, at present, Chinese cruise transportation mostly concentrated in Tianjin, Shanghai, Xiamen and Sanya. Among them, the number of the cruises treated Tianjin as their homeport accounted for $22.2 \%$, Tianjin is the only port located in the free trade zone within the international homeports, not only to be able to enjoy the cruise industry supporting policies given by the country, but also can enjoy the national policy of free trade zone at the same time. That helped Tianjin port attracting more major cruise companies in the world.

The international cruise reception number of Tianjin port increased year by year. On one hand, Tianjin port developed rapidly itself; on the other hand, due to the Tianjin port is adjacent to Beijing, which is the closest port to Beijing, Tianjin port has became the cruise center of the North China.

Table 1 The statistics of reception of the international cruises and entry-exit tourists in Tianjin port

\begin{tabular}{|c|c|c|c|c|c|c|c|}
\hline & 2010 & 2011 & 2012 & 2013 & 2014 & 2015 & 2016 \\
\hline $\begin{array}{c}\text { International Cruise } \\
(\text { ships })\end{array}$ & 40 & 31 & 35 & 70 & 55 & 102 & 128 \\
\hline $\begin{array}{c}\text { Tourists } \\
\text { (person) }\end{array}$ & 100,000 & 72,000 & 119,096 & 249,000 & 224,400 & 470,000 & 357,831 \\
\hline
\end{tabular}


Table 2 Major itineraries in Tianjin homeport

\begin{tabular}{|c|l|l|}
\hline Major Itinerary & \multicolumn{1}{|c|}{ Itineraries } & \multicolumn{1}{c|}{ Days } \\
\hline \multirow{5}{*}{$\begin{array}{c}\text { Japan and } \\
\text { South Korea }\end{array}$} & Tianjin-Chejudo-Tianjin & 4-7 days(5 days 4 nights) \\
\cline { 2 - 3 } & Tianjin-Nagasaki-Busan-Tianjin & 4-7 days(6 days 5 nights) \\
\cline { 2 - 3 } & Tianjin-Fukuoka-Nagasaki-Tianjin & 4-7 days(7 days 6 nights) \\
\cline { 2 - 3 } & Tianjin-Fukuoka-Sakaiminato-Busan-Tianjin & 4-7 days(7 days 6 nights) \\
\cline { 2 - 3 } Other Itinerary & Tianjin-Kobe-Yokohama-Muroran-Fukuoka-Tianjin & $\begin{array}{l}\text { 8-14 days(11 days10 } \\
\text { nights) }\end{array}$ \\
\cline { 2 - 3 } & Universal Routes & $\begin{array}{l}\text { Over 14 days(18 days17 } \\
\text { nights/46 days 45 nights) }\end{array}$ \\
\cline { 2 - 3 } & Australia and New Zealand Routes & $\begin{array}{l}\text { Over 14 days(18 days 17 } \\
\text { nights) }\end{array}$ \\
\hline
\end{tabular}

\section{SWOT Analysis of Tianjin Home Port Upgrading to Cruise Toursim Destinations}

Strength. Superior geographical location. Tianjin has superior geographical location which is located in the west coast of the Pacific Ocean, in the northeast of North China Plain. Since ancient times, Tianjin is a portal to the capital. It is the strategic pivot of Marine Silk Road which is also the intersection of "The Belt and Road". With excellent geographical location and traffic conditions, Tianjin has become an important hub connecting both at here and abroad, contacting between northern and southern part, communicate the eastern and western. Superior geographical location is easy to develop cruise routes directly through the surrounding tourist destinations in different regions or countries.

Cruise home port and completed supporting facilities. Tianjin international cruise home port is the only port in North China, also is the largest one. At the same time, the port is equipped with complete facilities such as boarding halls, duty-free shops, currency exchanging, express outlets and the sea-jet-one transport service counter and so on. Those give a high feasibility of homeport.

Weakness. Low attraction of tourism resources. Tianjin is rich in tourism resources, with a complete range of landscapes, such as mountains, rivers, lakes, seas and wetlands. It is the first batch of excellent tourist cities in China. Tianjin has a prominent position and influence in the past hundred years of Chinese modern history, and the blending of Chinese and Western cultures constitutes a unique human resource which builds a microcosm of the modern history of china. But the attraction of Tianjin tourism resources is poor, especially compared with the surrounding cities like Beijing. No matter the quantity or quality, there is no way to compare with Beijing. There is no core competitiveness.

Tianjin has a weak influence at here and abroad. The propaganda range of Tianjin's image is poorly small, resulting in the city images in domestic and foreign countries are not clear, the influence is weak. Of course, it is also led by the neighboring city --Beijing. Because the cruises in our country are just at the initial stage, in the international publicity, Tianjin was just publicized as Beijing's out port.

Opportunities. Broad tourist market. As the central city of the Bohai rim and the "gateway of the sea" in the north, the city of Tianjin is backed by a large tourist market of more than ten inland provinces and cities in northern china. Especially in the short term, besides the Beijing-Tianjin region, the potential development of the near distance tourist markets, such as Hebei, Shandong, Liaoning and Jilin, are very great. At the same time, according to the National Tourism Administration data showed that in recent years, the rate of international tourists in Tianjin continues to maintain high growth. Japan and South Korea are the two largest tourist markets in China, which is also adjacent to Tianjin.

Coordinated development strategy of Beijing and Tianjin. Beijing-Tianjin-Hebei collaborative development which is the core in three cities coordinately develop as a whole is requiring three 
cities gradually break the limited thinking, to achieve integrated development in economy, culture, transportation and tourism etc. Tianjin can take advantage of Beijing's rich tourism resources and powerful international influence to set up the image of the cruise destination in the world.

Threats. The threats of other home port cities. China's four major cruise terminals are Shanghai, Xiamen, Sanya and Tianjin. Compared with Tianjin, the other three home ports are the tourism attractions, more easily drawing support from the cruise home ports and upgrading to cruise destinations as soon as possible.

Passenger flow diversion of the surrounding originating port. In addition to the Tianjin cruise home port in North China, there are Dalian, Yantai and Qingdao starting ports as well. These three originating port cities are rich in tourism resources which are the famous tourist attractions in China, and backed by the northeast and Shandong tourist hinterland, that will help them to divert Tianjin cruise tourism market.

\section{Countermeasures of Tianjin Cruise Home Port Upgrading to Cruise Destination}

Government's Support. Upgrading to cruise destinations will achieve under the government's supporting. First, upgrading the top-level design of cruise destinations, and then introduce the relevant benefit policies. With the helping of various departments, finally organize relevant personnel and start the project.

Set up the Cruise Tourism Destination Image of Tianjin. The city image is the character of a city, to demonstrate its unique features. Generally having a special image and widely recognize often makes the cities become the world's focus, leading the world's cultural trend. Tianjin is the current largest cruise home port in China, Binhai New Area was officially established as the national cruise tourism experimentation area development in China, which has a great effect on the Tianjin setting up the cruise destination image of the city. The city of Tianjin should be with the golden opportunity of the development of China cruise tourism, repositioning the Tianjin city tourism image and shaping "cruise city" tourism brand in the world.

Strengthen Regional Cooperation. With the completion of the cruise home port of Tianjin, Tianjin has became the Bohai cruise tourism center, on the one hand, we must actively seek with Dalian, Yantai and Qingdao's cooperation to format the port group of Bohai area, realize the complementary functions, dislocation development, highlighting the advantages of routes in Japan and South Korea to attract South anchored cruise. Tianjin should establish the corporation between the provinces to achieve win-win goal. Strengthen cooperation with the port cities, such as signing a memorandum of cooperation, to achieve the sharing of cruise tourism resources and tourists.

Integrated Development of Beijing, Tianjin and Hebei. Tianjin's largest short board is the lack of tourist attraction, but its incomparable advantages are good location and the set up of cruise homeport. Beijing is the political, economic and cultural center in China, with unparalleled tourism resources; the only drawback is that it can not berth the international cruises. In the integration strategy of Beijing, Tianjin and Hebei, Beijing and Tianjin can complement each other, develop in a coordinated way, and cooperate in a win-win situation.

\section{Summary}

Tianjin cruise home port has a high feasibility that upgrades to the cruise destination. In the specific implementation process, not only need to expand their horizons, to seek common development and win-win cooperation with the surrounding city; but also to cooperate with the Tianjin municipal government, industry and other aspects. To contribute upgrading to the Tianjin cruise destinations jointly.

\section{References}

[1] X.N.Li: Economic Research Guide, (2013) No.6, p.198-199+212.(In Chinese) 
[2] Sh. Cao, X.L. Ye: Journal of Shanghai University of Engineering Science, (2017) No.6, p161-165.(In Chinese)

[3] J. Patricia, P. Annona: Asia Pacific Tourism Association (Macao, China July 13-16, 2010). p.329-338.

[4] G. Philip: Cruise Operations Management (Routledge, London 2012).

[5] X.N. Li: Journal of Jiamusi Education Institute,(2014)No.6,p.281-304.(In Chinese) 